Key Words:

Hydrogen

Temperature

Membrane

Catalyst

Membrane Electrode Assembly

\title{
CLOSE-OUT REPORT FOR HYS ELECTROLYZER COMPONENT DEVELOPMENT WORK AT SAVANNAH RIVER NATIONAL LABORATORY
}

\author{
H. R. Colon-Mercado \\ M. Elvington \\ D. T. Hobbs
}

JANUARY 2010

Savannah River National Laboratory

Savannah River Nuclear Solutions

Aiken, SC 29808

Prepared for the U.S. Department of Energy Under

Contract Number DE-AC09-08SR22470

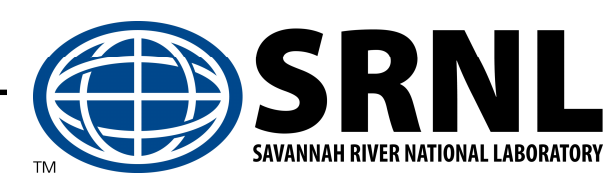




\section{DISCLAIMER}

This work was prepared under an agreement with and funded by the U.S. Government. Neither the U. S. Government or its employees, nor any of its contractors, subcontractors or their employees, makes any express or implied:

1. warranty or assumes any legal liability for the accuracy, completeness, or for the use or results of such use of any information, product, or process disclosed; or

2. representation that such use or results of such use would not infringe privately owned rights; or

3. endorsement or recommendation of any specifically identified commercial product, process, or service.

Any views and opinions of authors expressed in this work do not necessarily state or reflect those of the United States Government, or its contractors, or subcontractors.

Printed in the United States of America

Prepared for

U.S. Department of Energy 
Key Words:

Hydrogen

Temperature

Membrane

Catalyst

Membrane Electrode Assembly

\title{
CLOSE-OUT REPORT FOR HYS ELECTROLYZER COMPONENT DEVELOPMENT WORK AT SAVANNAH RIVER NATIONAL LABORATORY
}

\author{
H. R. Colon-Mercado \\ M. Elvington \\ D. T. Hobbs
}

JANUARY 2010

Savannah River National Laboratory

Savannah River Nuclear Solutions

Savannah River Site

Aiken, SC 29808

Prepared for the U.S. Department of Energy Under

Contract Number DE-AC09-08SR22470 


\section{TABLE OF CONTENTS}

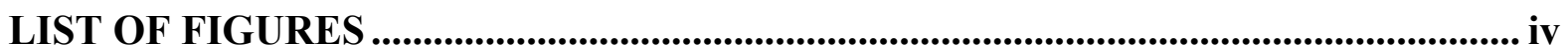

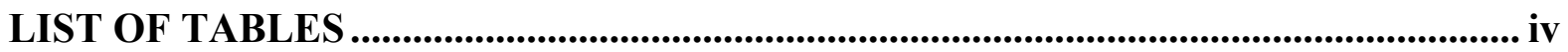

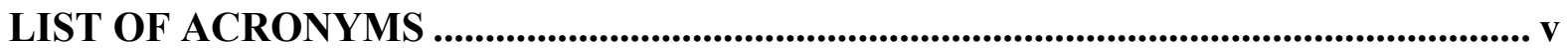

1.0 EXECUTIVE SUMMARY .......................................................................................... 1

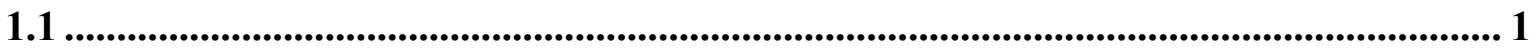

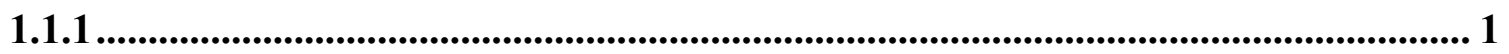

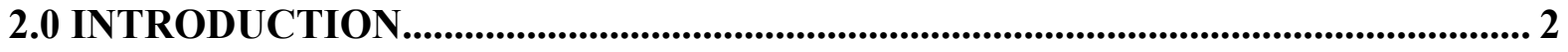

3.0 Experimental ........................................................................................................................ 4

3.1 Membrane Procurement and Preparation ............................................................................... 4

3.2 Membrane chemical stability measurement ................................................................ 5

3.3 Membrane $\mathrm{SO}_{2}$ transport Measurement ............................................................................ 5

3.4 Ionic conductivity measurement ...................................................................... 8

3.5 Electrolyzer performance ......................................................................................................... 8

3.6 Electrocatalyst Activity Measurement................................................................................ 9

4.0 DISCUSSION .................................................................................................................... 10

4.1 Membrane Durability............................................................................................................. 10

4.2 Membrane transport of $\mathrm{SO}_{2}$ and Electrolyzer performance..................................... 11

4.3 Electrocatalyst stability ....................................................................................................... 15

4.4 Electrocatalyst Activity ......................................................................................................... 17

5.0 CONCLUSIONS .............................................................................................................. 20

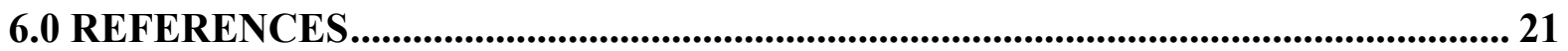




\section{LIST OF FIGURES}

Figure 1. Evaluated commercial and experimental membranes including a.) perfluorinated sulfonic acid, b.) polybenzimidizole, c.) sulfonated Diels-Alder polyphenylenes, and d.) perfluorocyclobutane-biphenyl vinyl ether hexafluoroisopropylidene.

Figure 2. Simplified schematic of the $\mathrm{SO}_{2}$ transport characterization cell consisting of two glass chambers joined by a Teflon bridge which houses the membrane, working electrode, and counter/reference electrode.

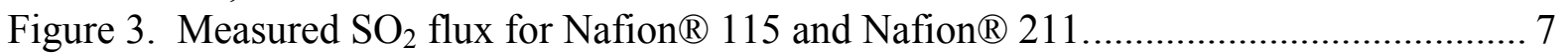

Figure 4. Simplified schematic of the catalyst characterization cell. ................................... 10

Figure 5. FTIR spectrum for PBI membrane Celtec V before (dotted line) and after (solid line) heating at reflux in $60 \mathrm{wt} \% \mathrm{H}_{2} \mathrm{SO}_{4}$ at $80{ }^{\circ} \mathrm{C}$ for 24 hours. ................................... 11

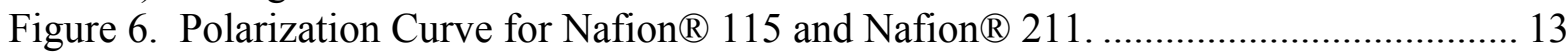

Figure 7. Typical cyclic voltammograms after consecutive cycling for $\mathrm{Ru} / \mathrm{C}$ in $30 \mathrm{wt} \%$

$\mathrm{H}_{2} \mathrm{SO}_{4}$ purged with $\mathrm{N}_{2}$ at room temperature. ………….......................................... 16

Figure 8. Normalized hydrogen desorption peak height after consecutive cycling for (a) $\mathrm{Pt} / \mathrm{C}$ and $\mathrm{PtM} / \mathrm{C}(\mathrm{M}=\mathrm{Co}, \mathrm{Cr}, \mathrm{Fe})$ and (b) $\mathrm{Ru} / \mathrm{C}$ and $\mathrm{PtM} / \mathrm{C}\left(\mathrm{M}=\mathrm{Ru}\right.$, Ir) in $30 \mathrm{wt} \% \mathrm{H}_{2} \mathrm{SO}_{4}$ purged with $\mathrm{N}_{2}$ at room temperature.

Figure 9. Typical Tafel plot for $\mathrm{PtCr} / \mathrm{C}$ in $30 \mathrm{wt} \%$ sulfuric acid, saturated with $\mathrm{SO}_{2}$ at room temperature. Three different potential cycles are shown.

Figure 10. Open circuit potential for the different catalysts at the beginning of the test and after reaching near steady state conditions. Tested in $30 \mathrm{wt} \%$ sulfuric acid, saturated with $\mathrm{SO}_{2}$ at room temperature.

\section{LIST OF TABLES}

Table 1. $\mathrm{SO}_{2}$ flux, $\mathrm{SO}_{2}$ transport, conductivity, and current density (performance in HyS electrolyzer) is shown along with membrane thickness for a number of commercially available and experimental membranes. 


\section{LIST OF ACRONYMS}

\begin{tabular}{ll} 
ATR & attenuated total reflectance \\
BPVE & perfluorocyclobutane-biphenyl vinyl ether \\
BPVE-6F & perfluorocyclobutane-biphenyl vinyl ether hexafluoroisopropylidene \\
CV & Cyclic Voltammogram \\
EIS & Electrochemical Impedance Spectroscopy (EIS) \\
EW & equivalent weight \\
FEP & fluorinated ethylene propylene \\
FTIR & Fourier transform infrared spectroscopy \\
GES & Giner Electrochemical Systems \\
HyS & hybrid sulfur \\
IR & infrared spectroscopy \\
LSV & linear sweep voltammetry \\
MEA & membrane electrode assembly \\
OCP & open circuit potential \\
PA & phosphoric acid \\
PBI & polybenzimidizole \\
PEM & proton exchange membrane \\
PFSA & perfluorinated sulfonic acid \\
S-PFCB & sulfonated perfluorocyclobutyl aromatic ether polymer \\
SDAPP & sulfonated Diels-Alder polyphenylenes \\
SDE & sulfur dioxide depolarized electrolyzer \\
SEM & Scanning electron microscope \\
SHE & standard hydrogen electrode \\
SNL & Sandia National Laboratory \\
SRNL & Savannah River National Laboratory \\
\hline
\end{tabular}




\subsection{EXECUTIVE SUMMARY}

The chemical stability, sulfur dioxide transport, ionic conductivity, and electrolyzer performance have been measured for several commercially available and experimental proton exchange membranes (PEMs) for use in a sulfur dioxide depolarized electrolyzer (SDE). The SDE's function is to produce hydrogen by using the Hybrid Sulfur (HyS) Process, a sulfur based electrochemical/thermochemical hybrid cycle. Membrane stability was evaluated using a screening process where each candidate PEM was heated at $80{ }^{\circ} \mathrm{C}$ in 63.5 wt. $\% \mathrm{H}_{2} \mathrm{SO}_{4}$ for 24 hours. Following acid exposure, chemical stability for each membrane was evaluated by FTIR using the ATR sampling technique. Membrane $\mathrm{SO}_{2}$ transport was evaluated using a two-chamber permeation cell. $\mathrm{SO}_{2}$ was introduced into one chamber whereupon $\mathrm{SO}_{2}$ transported across the membrane into the other chamber and oxidized to $\mathrm{H}_{2} \mathrm{SO}_{4}$ at an anode positioned immediately adjacent to the membrane. The resulting current was used to determine the $\mathrm{SO}_{2}$ flux and $\mathrm{SO}_{2}$ transport. Additionally, membrane electrode assemblies (MEAs) were prepared from candidate membranes to evaluate ionic conductivity and selectivity (ionic conductivity vs. $\mathrm{SO}_{2}$ transport) which can serve as a tool for selecting membranes. MEAs were also performance tested in a HyS electrolyzer measuring current density versus a constant cell voltage $\left(1 \mathrm{~V}, 80{ }^{\circ} \mathrm{C}\right.$ in $\mathrm{SO}_{2}$ saturated $30 \mathrm{wt} \% \mathrm{H}_{2} \mathrm{SO}_{4}$ ). Finally, candidate membranes were evaluated considering all measured parameters including $\mathrm{SO}_{2}$ flux, $\mathrm{SO}_{2}$ transport, ionic conductivity, HyS electrolyzer performance, and membrane stability. Candidate membranes included both PFSA and nonPFSA polymers and polymer blends of which the non-PFSA polymers, BPVE-6F and PBI, showed the best selectivity.

Testing examined the activity for the sulfur dioxide oxidation of platinum base electrocatalyst in $30 \mathrm{wt} \%$ sulfuric acid solution. Linear sweep voltammetry showed an increase in activity when catalysts in which Pt is alloyed with non-noble transition metals such as cobalt, chromium and iron. However when Pt is alloyed with noble metals, such as iridium or ruthenium, the kinetic activity as well as the stability decreases. 


\subsection{INTRODUCTION}

Continually increasing energy demands coupled with reliance on a diminishing supply of nonrenewable fossil fuels provides the impetus for innovative research into alternative energy generation and storage systems. One possible solution is centered on the energy carrier hydrogen, which contains the highest energy per mass ratio of any conventional fuel. Global scale quantities of hydrogen will be required for the ensuing economic transformation and major efforts are underway worldwide to develop the technologies required for this transition. These demands can be met by water electrolysis or through thermochemical water splitting cycles. Water electrolysis offers several advantages over other production methods [1], however, the technology required and energy input can make hydrogen produced by this method expensive. Thermochemical water splitting cycles offer an alternative highly efficient route for hydrogen production [2]. Among the many possible thermochemical cycles for the production of hydrogen, the sulfur-based cycles lead the competition in overall energy efficiency.

The Hybrid Sulfur (HyS) Process is a sulfur-based thermochemical cycle containing a low energy electrolysis step making it a thermo/electrochemical hybrid process. In this process sulfuric acid is thermally decomposed at high temperature $\left(>800{ }^{\circ} \mathrm{C}\right)$ producing $\mathrm{SO}_{2}[\mathrm{r} 1]$. $\mathrm{H}_{2} \mathrm{SO}_{4}$ saturated with $\mathrm{SO}_{2}$ is then pumped into a sulfur dioxide-depolarized electrolyzer (SDE). The SDE electrochemically oxidizes sulfur dioxide to form sulfuric acid at the anode [r2] and reduces protons to form hydrogen at the cathode [r3]. The overall electrochemical reaction consists of the production of $\mathrm{H}_{2} \mathrm{SO}_{4}$ and $\mathrm{H}_{2}$ [r4], while the entire cycle produces $\mathrm{H}_{2}$ and $\mathrm{O}_{2}$ from $\mathrm{H}_{2} \mathrm{O}$ with no side products [r5].

$$
\begin{aligned}
& \mathrm{H}_{2} \mathrm{SO}_{4} \rightarrow \mathrm{SO}_{2}+1 / 2 \mathrm{O}_{2}+\mathrm{H}_{2} \mathrm{O} \\
& \mathrm{SO}_{2}+2 \mathrm{H}_{2} \mathrm{O} \rightarrow \mathrm{H}_{2} \mathrm{SO}_{4}+2 \mathrm{H}^{+}+2 \mathrm{e}^{-} \\
& 2 \mathrm{H}^{+}+2 \mathrm{e}^{-} \rightarrow \mathrm{H}_{2} \\
& \mathrm{SO}_{2}+2 \mathrm{H}_{2} \mathrm{O} \rightarrow \mathrm{H}_{2} \mathrm{SO}_{4}+\mathrm{H}_{2} \\
& 2 \mathrm{H}_{2} \mathrm{O} \rightarrow 2 \mathrm{H}_{2}+\mathrm{O}_{2}
\end{aligned}
$$


HyS electrolysis $\left(\mathrm{SO}_{2}\right.$ oxidation) [r2] has a reversible half cell potential of $-0.158 \mathrm{~V}$ (SHE) [3], while low temperature water electrolysis has a reversible half cell potential of $-1.23 \mathrm{~V}$ (SHE). Thus, the HyS process requires much less electrical energy input than water electrolysis. Due to ohmic, kinetic, and mass transport overpotential losses, an operating potential of $0.6 \mathrm{~V}$ has been targeted for the HyS electrolyzer at a current density of $500 \mathrm{~mA}$ $\mathrm{cm}^{-2}$.

Development of the SDE began in the late 1970s utilizing a parallel-plate electrolyzer with a separator/membrane to keep the anolyte and catholyte compartments separate [4]. Since this work in the early 1980s, significant advances have occurred in electrolyzer technology principally in the area of hydrogen fuel cells. Advanced hydrogen fuel cells employ proton conductive membranes with catalyst layers deposited on both sides of the membrane, forming the respective anode and cathode of the electrochemical cell. The layered structure containing membrane and electrode catalysts is referred to as the MEA. Upon resumption of HyS work in 2005, the fuel cell MEA design concept was applied to the SDE $[5,6]$. The MEA concept results in a much smaller cell footprint than conventional parallel plate technology, which is a major benefit when implementing the SDE on a commercial scale.

There are several requirements of a PEM for the successful functioning of a HyS electrolyzer. The PEM must be stable in highly corrosive solution ( $>30 \mathrm{wt} \% \mathrm{H}_{2} \mathrm{SO}_{4}$ saturated with $\left.\mathrm{SO}_{2}\right)$ and at high operating temperature $\left(>80{ }^{\circ} \mathrm{C}\right)$, allow minimal transport of $\mathrm{SO}_{2}$, and must maintain high ionic conductivity. Ideally, operating temperatures well above $80^{\circ} \mathrm{C}$ are desired with acid concentrations greater than $50 \mathrm{wt} \% \mathrm{H}_{2} \mathrm{SO}_{4}$. These conditions allow the electrolyzer to function at low cell potential and high current density thus minimizing the energy input and maximizing hydrogen output. Lastly, the PEM serves to separate the anolyte reagents from the hydrogen output to prevent the production of undesired sulfur-based side reaction products and poisoning of the cathode catalyst. 


\subsection{EXPERIMENTAL}

\subsection{MEMBRANE PROCUREMENT AND PREPARATION}

The selection process of commercially available and experimental membranes took into account: thickness, equivalent weight (EW), conductivity, chemical stability, and permeability to uncharged molecules. Prior to testing, all membranes were hydrated by immersing in deionized water for several minutes. Commercial membranes included perfluorinated sulfonic acid (PFSA) membranes [7] from DuPont and polybenzimidizole (PBI) [8] membranes from BASF, Figure 1. Experimental membranes were synthesized with the primary objective of reducing the transport of neutral charge species such as dissolved $\mathrm{SO}_{2}$. These membranes included hydrated, sulfonated Diels-Alder polyphenylenes (SDAPP) [9] from Sandia National Laboratory (SNL); stretched recast Nafion ${ }^{\circledR}$ and PFSA/fluorinated ethylene propylene (FEP) blends from Case Western Reserve University; hydrated treated Nafion $^{\circledR} 115$ from Giner Electrochemical Systems (GES); and perfluorocyclobutane-biphenyl vinyl ether (BPVE) and perfluorocyclobutane-biphenyl vinyl ether hexafluoroisopropylidene (BPVE-6F) polymer blends from Clemson University (Figure 1) [10].

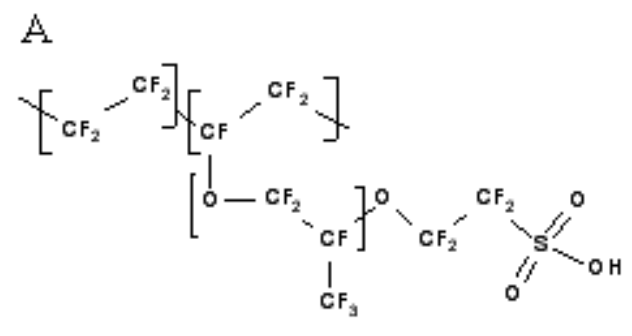

B

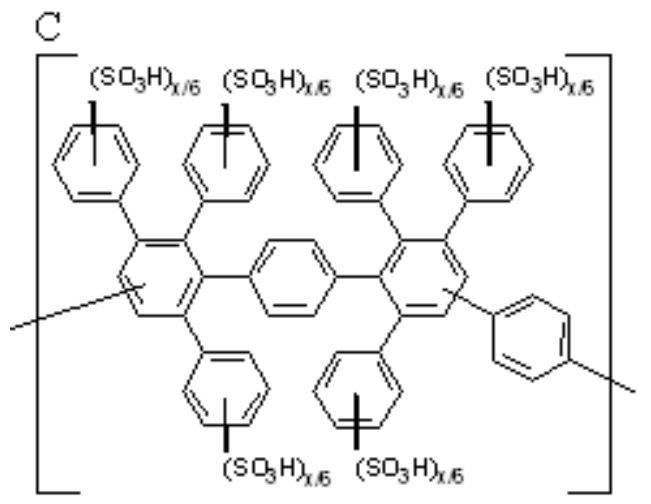

$\mathrm{D}$

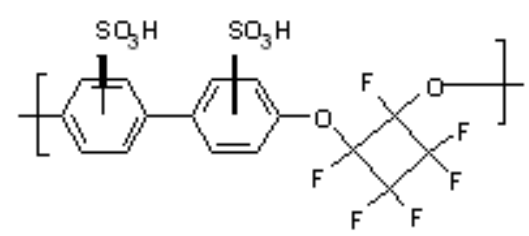


Figure 1. Evaluated commercial and experimental membranes including a.) perfluorinated sulfonic acid, b.) polybenzimidizole, c.) sulfonated Diels-Alder polyphenylenes, and d.) perfluorocyclobutane-biphenyl vinyl ether hexafluoroisopropylidene.

\subsection{MEMBRANE CHEMICAL STABILITY MEASUREMENT}

The chemical stability of the membranes in a corrosive environment was examined using a screening method to provide insight into the potential long-term performance. All membranes were exposed to 9.2 molar $(63.5 \mathrm{wt} \%) \mathrm{H}_{2} \mathrm{SO}_{4}$ at $80{ }^{\circ} \mathrm{C}$ for 24 hours. Following acid exposure, the membranes were rinsed and stored in deionized water until analysis. Fourier transform infrared spectroscopy (FTIR) was used with the attenuated total reflectance (ATR) sampling technique. IR spectra taken before and after acid exposure were compared to determine impact on membrane functional groups. FTIR spectra were measured with a Jasco FT/IR-6300 instrument before and after exposure to sulfuric acid solution.

\subsection{MEMBRANE $\mathrm{SO}_{2}$ TRANSPORT MEASUREMENT}

Membrane transport of $\mathrm{SO}_{2}$ was evaluated under non-polarized conditions using a permeation cell designed and fabricated at Savannah River National Laboratory (SRNL); a schematic of the cell is shown in Figure 2. The cell consists of two glass chambers joined by a Teflon ${ }^{\mathrm{TM}}$ bridge where the membrane is secured. The bridge consists of a diffusion layer in the left chamber where acid saturated with $\mathrm{SO}_{2}$ is forced by pump A into the anolyte-membrane interface. Additionally, the diffusion layer presses the membrane to the working electrode, which is supported by a perforated tantalum plate that provides electrical connection to the working electrode. Finally, a non-conductive diffusion media separates the tantalum support from the counter electrode in order to allow the flow of fresh acid pumped by pump B to the counter electrode without short circuiting the cell. 


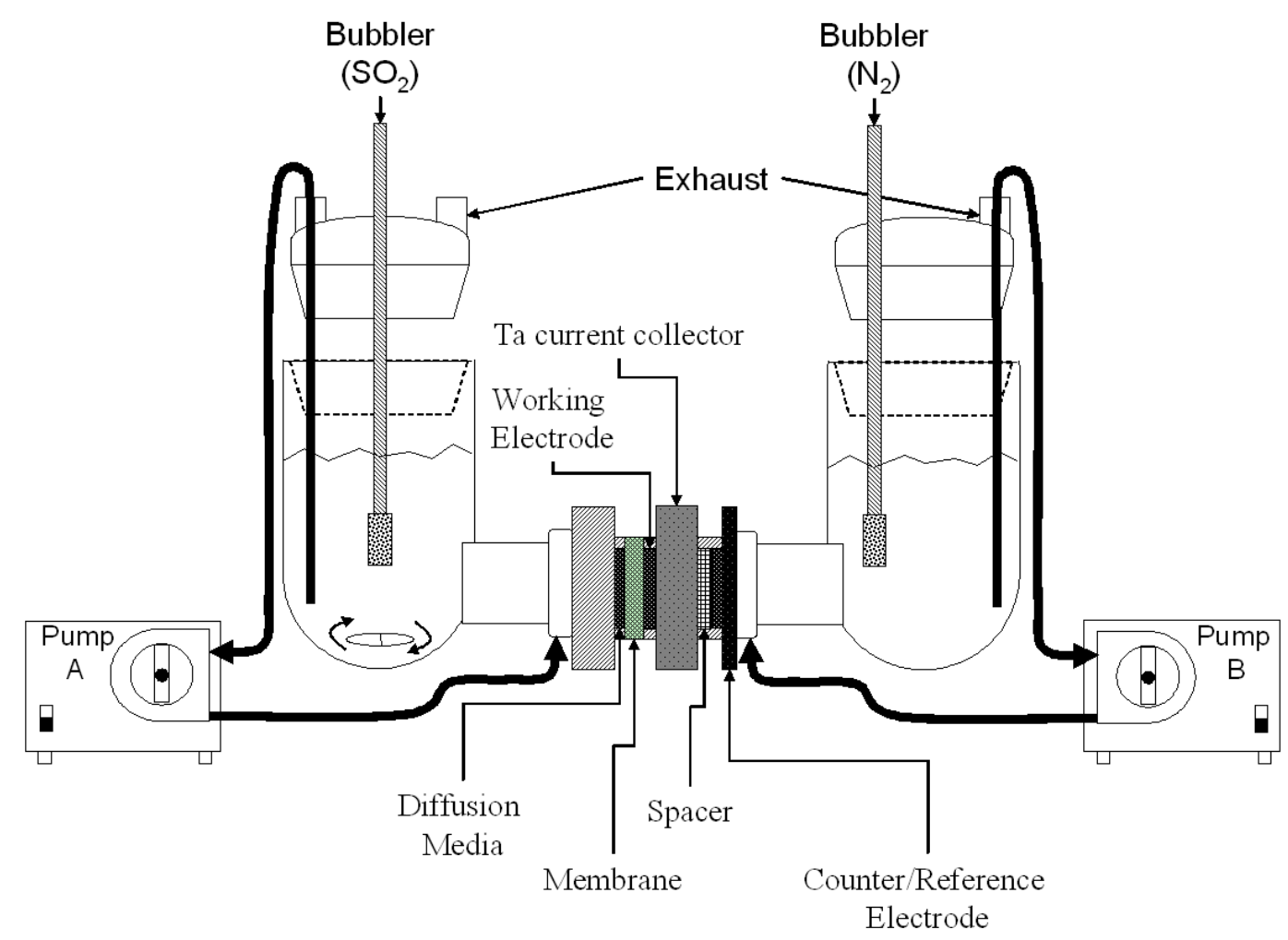

Figure 2. Simplified schematic of the $\mathrm{SO}_{2}$ transport characterization cell consisting of two glass chambers joined by a Teflon bridge which houses the membrane, working electrode, and counter/reference electrode.

During measurements both chambers were filled with $30 \mathrm{wt} \%$ sulfuric acid and purged of oxygen by flowing nitrogen. A two-electrode system consisting of a platinum mesh working electrode and a porous carbon counter electrode was used during measurements. $\mathrm{SO}_{2}$ transport was determined by measuring the current as a function of time while a constant potential of $1.2 \mathrm{~V}$ was applied using a PARSTAT 2273 electrochemical analyzer. Once the background current stabilized close to zero, $\mathrm{SO}_{2}$ was introduced into the cell within the left chamber by bubbling. $\mathrm{SO}_{2}$ permeating through the membrane was oxidized to sulfuric acid by the working electrode. The permeation current increased with time until steady-state conditions are reached and no change in flux is observed. $\mathrm{SO}_{2}$ transport was measured for a period of one hour and then analyzed. If the current did not reach a steady state within the first hour, the experiment was continued for an additional hour and then reassessed. The time required to reach steady state is mostly dependent on the equilibration time between the membrane and the liquid electrolyte. Assuming all the $\mathrm{SO}_{2}$ transported was 
electrochemically oxidized, the $\mathrm{SO}_{2}$ flux, $J_{\mathrm{SO}_{2}}$, can be calculated from the current response using Faraday's Law,

$$
J_{\mathrm{SO}_{2}}=\frac{i}{n F}
$$

where $i$ is the current density in A cm $\mathrm{cm}^{-2}, F$ is Faraday's constant (96,487 C/eq.), and $n$ is the number of electrons transferred assuming [r2]. Nafion ${ }^{\circledR} 115$ and Nafion ${ }^{\circledR} 211$ were used as baselines for all $\mathrm{SO}_{2}$ flux and $\mathrm{SO}_{2}$ transport measurements. A plot of $\mathrm{SO}_{2}$ flux over time for the two baseline materials is shown as an example, Figure 3.

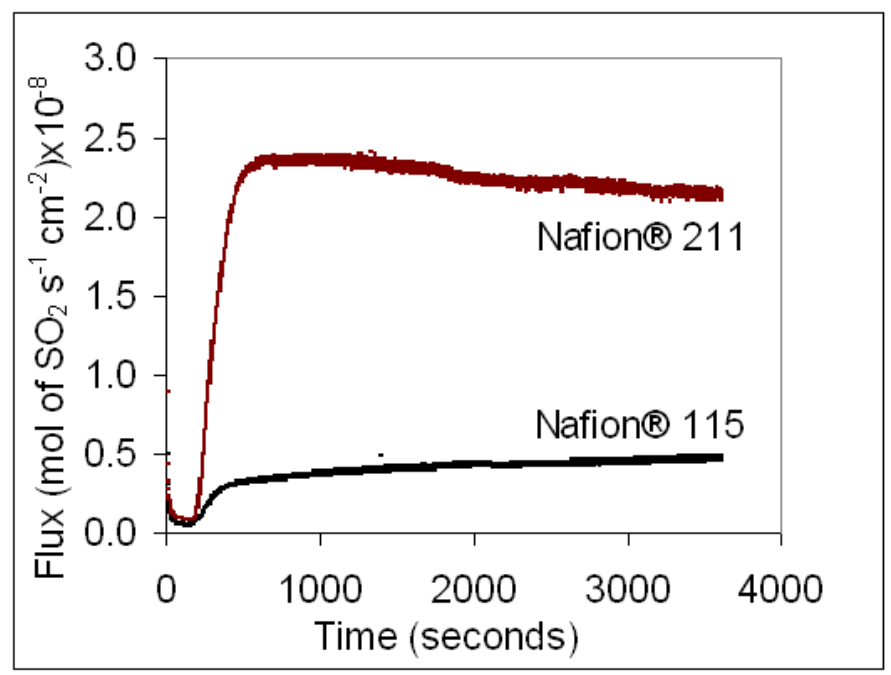

Figure 3. Measured $\mathrm{SO}_{2}$ flux for $\mathrm{Nafion}{ }^{\circledR} 115$ and $\mathrm{Nafion}{ }^{\circledR} 211$.

The solubility of $\mathrm{SO}_{2}$ within the membranes is unknown so $D$, the $\mathrm{SO}_{2}$ diffusion coefficient, cannot be determined. $\mathrm{SO}_{2}$ transport can, however, be estimated from Fick's first law of diffusion by substituting the solubility of dissolved $\mathrm{SO}_{2}$ in the membrane for the bulk $\mathrm{SO}_{2}$ concentration,

$$
\mathrm{SO}_{2} \text { transport }=\frac{J_{S_{2}} L}{C_{0}}
$$

where $J_{\mathrm{SO}_{2}}$ is the $\mathrm{SO}_{2}$ flux, $L$ is the thickness of the membrane, and $C_{0}$ is the bulk concentration of $\mathrm{SO}_{2}$ (estimated to be $1.09 \mathrm{M}$ in $30 \mathrm{wt} \% \mathrm{H}_{2} \mathrm{SO}_{4}$ and $0.952 \mathrm{M}$ in $50 \mathrm{wt} \%$ $\left.\mathrm{H}_{2} \mathrm{SO}_{4}\right)[3]$. 


\subsection{IONIC CONDUCTIVITY MEASUREMENT}

The ionic conductivity of each membrane was measured as was the performance in a HyS electrolyzer cell. Membrane Electrode Assemblies (MEAs) were prepared in order to measure these properties. A Paasche Millennium double action airbrush was used for MEA preparation to apply the catalyst "ink" via the spray-deposition technique. Typical catalyst layers consist of $25 \mathrm{wt} \% \mathrm{Nafion}^{\circledR}$ ionomer as a binder, and $75 \mathrm{wt} \%$ platinized carbon (TKK; $45.9 \mathrm{wt} \% \mathrm{Pt}$ ). Anode and cathode catalyst layers were targeted at $1.8 \mathrm{mg} \mathrm{Pt} \mathrm{cm}^{-2}$ and $0.9 \mathrm{mg}$ $\mathrm{Pt} \mathrm{cm}^{-2}$ respectively. A PARSTAT 2273 potentiostat (Princeton Applied Research) was used for all electrochemical measurements.

Electrochemical Impedance Spectroscopy (EIS) was used to evaluate the ionic resistivity $(\rho)$ for each membrane. For this measurement MEAs were used in a HyS electrolyzer cell to minimize the contact resistance. After allowing the membrane to equilibrate for several minutes, a $10 \mathrm{mV}$ vs. OCP (open circuit potential) sinusoidal voltage was applied across the membrane at frequencies ranging from $500 \mathrm{kHz}$ to $200 \mathrm{~Hz}$. The resulting response was displayed in the form of a Nyquist plot. The resistance was calculated from the value of the real impedance when the imaginary response was zero. The ionic conductivity, $\lambda$, was calculated using the following equation,

$$
\lambda=\frac{L}{Z_{\text {real }} A}
$$

where $L$ is the thickness of the membrane, $A$ is the area available for proton conduction, and $Z_{\text {real }}$ is the real part of the impedance response when the imaginary impedance is zero.

\subsection{ELECTROLYZER PERFORMANCE}

Electrolyzer performance was evaluated in a HyS cell by applying a potential of $1 \mathrm{~V}$ across the MEA and measuring the current density over time. The anodic chamber contained 30 wt $\% \mathrm{H}_{2} \mathrm{SO}_{4}$ saturated with $\mathrm{SO}_{2}$ while the cathodic chamber contained deionized water. Prior to electrolysis both chambers were purged of oxygen by flowing argon. A potential of $1 \mathrm{~V}$ was then applied. Once the background current stabilized close to zero, $\mathrm{SO}_{2}$ was introduced into the anolyte by bubbling and the resulting current due to $\mathrm{SO}_{2}$ oxidation was measured. 


\subsection{ELECTROCATALYST ACTIVITY MEASUREMENT}

The cell consisted of a glass vial with two compartments covered with a Teflon ${ }^{\mathrm{TM}}$ cap and separated with a fine glass frit. The three electrodes, which included a silver-silver chloride reference electrode, a platinum wire as the counter electrode, and a glassy carbon disk electrode (GCE), were inserted through the Teflon ${ }^{\mathrm{TM}}$ cap. The counter electrode was inserted in the second compartment to prevent reduction products from affecting the working electrode. The counter electrode compartment was purged with $\mathrm{N}_{2}$ at all times. Figure 4 shows the simplified schematic of the catalyst characterization cell. To load the catalyst onto the GCE, a catalyst ink was prepared by ultrasonically blending the catalyst $(2 \mathrm{mg})$ with $1 \mathrm{~mL}$ of deionized, distilled water for $15 \mathrm{~min}$ in an ultrasonic bath. The ink $(8 \mu \mathrm{L})$ was then placed on the GCE surface. After drying, a volume of $\sim 2 \mu \mathrm{L}$ of a mixture 1:20 of Nafion ${ }^{\circledR}$ solution ( $5 \mathrm{wt} \%$ from Aldrich) and methyl alcohol (Sigma) was applied on the dry catalyst to ensure adhesion on the GCE surface. Electrochemical characterization of each catalyst material featured cyclic voltammetry (CV) which was obtained using a PARSTAT 2273 electrochemical analyzer. Sulfuric acid solutions were prepared by diluting reagent grade sulfuric acid (Fisher Scientific) with deionized, distilled water. Prior to the measurements all solutions were purged of oxygen by bubbling nitrogen. 


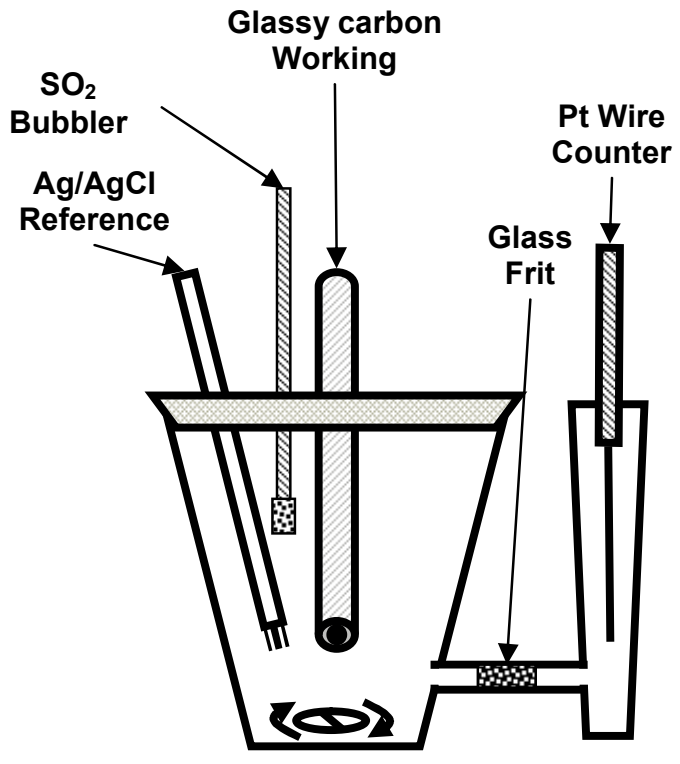

Figure 4. Simplified schematic of the catalyst characterization cell.

CVs were performed at a scan rate of $100 \mathrm{mV} / \mathrm{sec}$ and in a potential window between 1200 $\mathrm{mV}$ and $-200 \mathrm{mV}$ vs. $\mathrm{Ag} / \mathrm{AgCl}$. The experiments were carried out at a temperature of $25^{\circ} \mathrm{C}$ and a sulfuric acid concentration of $30 \mathrm{wt} \%$. The curves were repeated until a stable performance was obtained. $\mathrm{CV}$ measurement was performed starting from the anodic potential and going in the cathodic direction.

Linear sweep voltammetry (LSV) was performed to establish the equilibrium potential for sulfur dioxide oxidation using a window of $0.604 \mathrm{~V}$ to $0.204 \mathrm{~V}$ (vs $\mathrm{Ag} / \mathrm{AgCl}$ ). The $\mathrm{Ag} / \mathrm{AgCl}$ reference electrode was calibrated versus ferrocene throughout the course of experimentation to ensure no potential drift occurred due to contamination of the reference electrode. LSVs measuring $\mathrm{SO}_{2}$ oxidation potentials were taken at room temperature in 30 wt.\% $\mathrm{H}_{2} \mathrm{SO}_{4}$ saturated with $\mathrm{SO}_{2}$ by bubbling.

\subsection{DISCUSSION}

\subsection{MEMBRANE DURABILITY}


The chemical stability of the membranes in a corrosive environment was examined to provide insight into the potential long-term performance. FTIR spectra taken before and after acid exposure were compared to determine impact on membrane functional groups. It was found that all PFSA type membranes suffered no measurable degradation when exposed to $63.5 \mathrm{wt} \% \mathrm{H}_{2} \mathrm{SO}_{4}$ for 24 hours at $80^{\circ} \mathrm{C}$. Also, no degradation was observed for SDAPP and S-PFCB samples. A spectral shift was observed in the 800 to $1200 \mathrm{~cm}^{-1}$ region for the PBI membrane, Celtec V, which corresponds to vibrations attributed to the doped acid anions, Figure 5 [11]. This small shift to higher wave numbers possibly indicates loss of $\mathrm{H}_{3} \mathrm{PO}_{4}$ from the membrane along with uptake of $\mathrm{H}_{2} \mathrm{SO}_{4}$. It has been previously shown that a $\mathrm{H}_{2} \mathrm{SO}_{4}$ doped PBI membrane has comparable conductivity, depending on doping level, to a $\mathrm{H}_{3} \mathrm{PO}_{4}$ doped membrane $[11,12]$. The high electrolyzer performance, both initially and after multiple hours of electrolysis, also suggests that if $\mathrm{H}_{3} \mathrm{PO}_{4} / \mathrm{H}_{2} \mathrm{SO}_{4}$ exchange is occurring, no detrimental impact is apparent. No other spectral shifts are observed for the PBI membrane indicating the polymer backbone is intact

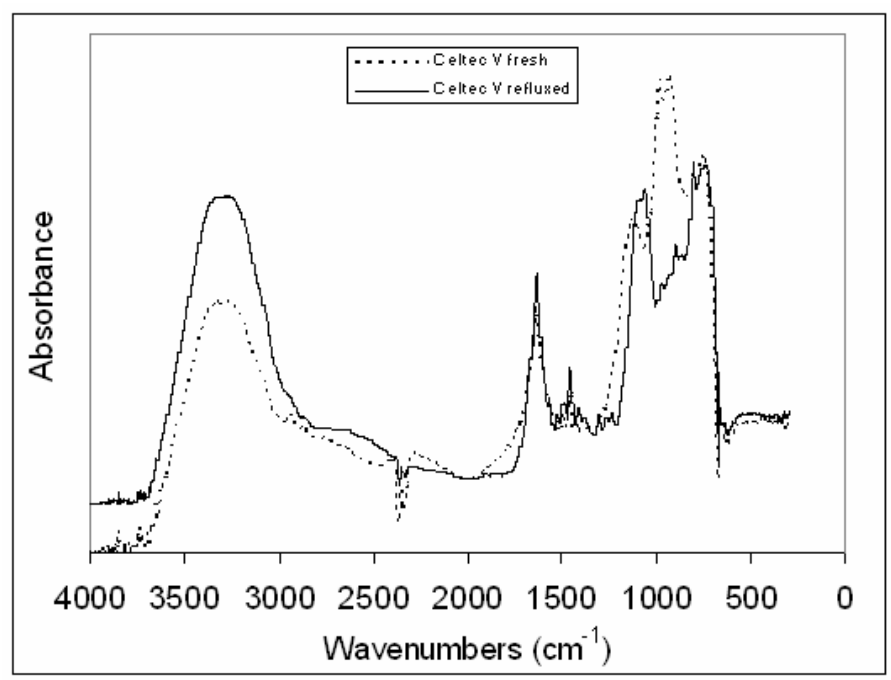

Figure 5. FTIR spectrum for PBI membrane Celtec V before (dotted line) and after (solid line) heating at reflux in $60 \mathrm{wt} \% \mathrm{H}_{2} \mathrm{SO}_{4}$ at $80{ }^{\circ} \mathrm{C}$ for 24 hours.

\subsection{MEMBRANE TRANSPORT OF $\mathrm{SO}_{2}$ AND ELECTROLYZER PERFORMANCE}

$\mathrm{SO}_{2}$ flux, and $\mathrm{SO}_{2}$ transport were determined for several commercially available and experimental membranes and tabulated along with membrane thickness in Table 1. Nafion ${ }^{\circledR}$ 
115, equivalent weight (EW) 1100, is utilized in current HyS electrolyzer testing and, therefore, serves as a baseline for this work.

Table 1. $\mathrm{SO}_{2}$ flux, $\mathrm{SO}_{2}$ transport, conductivity, and current density (performance in HyS electrolyzer) is shown along with membrane thickness for a number of commercially available and experimental membranes.

\begin{tabular}{|c|c|c|c|c|c|c|}
\hline Manufacturer and ID & $\begin{array}{l}\text { Membrane } \\
\text { Classification }\end{array}$ & 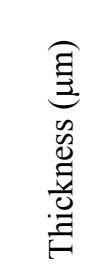 & 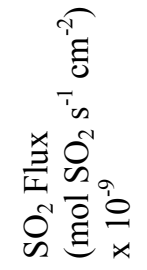 & 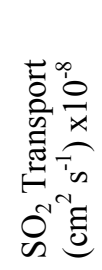 & 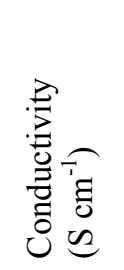 & 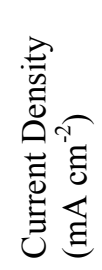 \\
\hline Dupont Nafion $\AA 115$ & PFSA & 127 & 5.23 & 6.10 & 0.0241 & 270 \\
\hline Dupont Nafion $® 211$ & PFSA & 25 & 21.8 & 5.09 & 0.0159 & 393 \\
\hline Dupont Bi-layer & $\begin{array}{l}\text { Perflourinated } \\
\text { Carboxyl/Sulfonic Acid }\end{array}$ & 140 & 0.11 & 0.14 & $\mathrm{a}$ & 0.010 \\
\hline Dupont 1500EW & 1500EW PFSA & 100 & 0.14 & 0.13 & $\mathrm{a}$ & 0.005 \\
\hline Dupont 112/pvp46 & Treated PFSA & 50 & 6.61 & 3.08 & 0.0036 & 128 \\
\hline Dupont $1135 /$ pvp48 & Treated PFSA & 90 & 6.01 & 4.90 & 0.0064 & 123 \\
\hline GES 672-90-1 & Treated PFSA & 127 & 12.6 & 14.7 & & \\
\hline GES 672-90-2 & Treated PFSA & 127 & 10.2 & 11.9 & & \\
\hline Case 1 & Stretched PFSA & 55 & 10.5 & 5.28 & & \\
\hline Case 4 & Stretched PFSA & 63 & 19.8 & 11.7 & & \\
\hline Case $60-40-2$ & PFSA-FEP blend & 62 & 5.88 & 3.35 & & \\
\hline Case $50-50-2$ & PFSA-FEP blend & 55 & 5.96 & 3.01 & 0.0034 & 155 \\
\hline Case 45-55-2 & PFSA-FEP blend & 53 & 4.09 & 1.99 & 0.0096 & 228 \\
\hline Sandia SDAPP5192C & SDAPP & $50-85$ & 11.1 & 7.79 & 0.0328 & 286 \\
\hline Clemson B(2) & BPVE & 18 & 21.2 & 3.50 & 0.0048 & 320 \\
\hline Clemson B1F1(1) & BPVE-6F (1:1) & 16 & 16.2 & 2.37 & 0.0063 & 337 \\
\hline Clemson B2F1(3) & BPVE-6F (2:1) & 19 & 17.6 & 3.07 & 0.0109 & 335 \\
\hline BASF Celtec-V & PBI & 100 & 2.14 & 1.99 & & 344 \\
\hline
\end{tabular}

a. conductivity was to low to measure.

PFSA membranes, developed for low temperature $\left(80^{\circ} \mathrm{C}\right) \mathrm{PEM}$ fuel cells, are known to have good chemical stability and conductivity, and have shown good performance in a HyS electrolyzer, see Figure 6. However, $\mathrm{SO}_{2}$ transport is unacceptably high, leading to the formation of sulfur containing impurities at the cathode and ultimately reduced operational lifetime. 


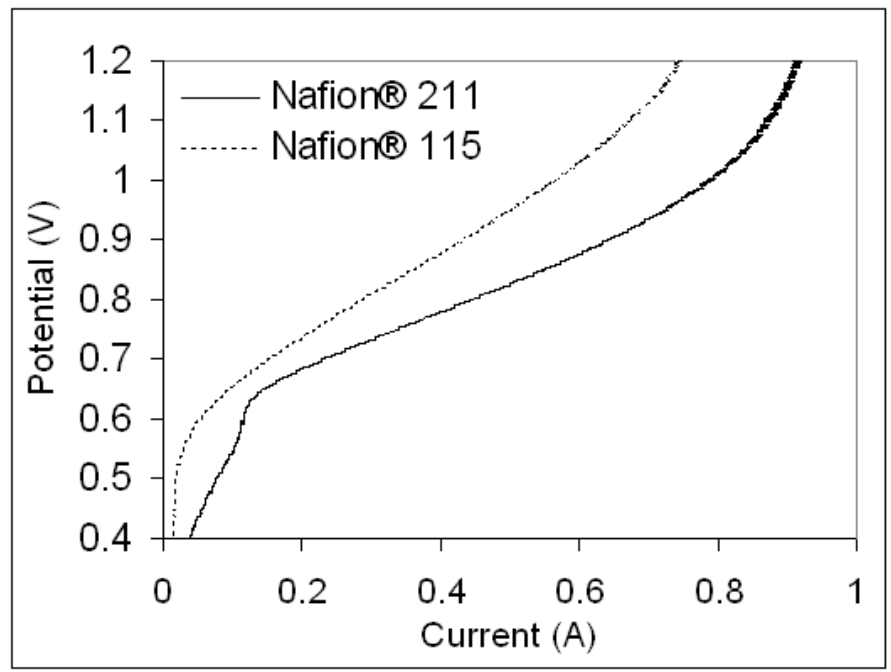

Figure 6. Polarization Curve for Nafion ${ }^{\circledR} 115$ and Nafion ${ }^{\circledR} 211$.

A number of PFSA-type membranes were prepared to reduce the transport of small neutral molecules such as $\mathrm{SO}_{2}$ including: a bilayer of polyfluorinated carboxyl and sulfonic acid, Nafion ${ }^{\circledR} 1500 \mathrm{EW}$, and two treated Nafion ${ }^{\circledR}$ membranes from Dupont; two treated PFSA membranes from GES; and stretched recast PFSA membranes, and PFSA-FEP blends from Case Western Reserve University. Of the PFSA family of membranes, untreated Nafion ${ }^{\circledR}$ had the highest through-plane conductivity $\left(0.0241 \mathrm{~S} \mathrm{~cm}^{-1}\right)$ and showed the best performance $\left(270 \mathrm{~mA} \mathrm{~cm}{ }^{-2}\right)$, while having mediocre $\mathrm{SO}_{2}$ transport $\left(6.10 \times 10^{-8} \mathrm{~cm}^{2} \mathrm{~s}^{-1}\right)$. Standard deviations for $\mathrm{SO}_{2}$ flux and $\mathrm{SO}_{2}$ transport measurements were typically less than $10 \%$ while standard deviations for electrolyzer performance was typically less than $2 \%$. The $1500 \mathrm{EW}$ Nafion ${ }^{\circledR}$ and the Nafion ${ }^{\circledR}$ bilayer had by far the lowest conductivity and performance but also had by far the lowest $\mathrm{SO}_{2}$ flux and $\mathrm{SO}_{2}$ transport of any membrane tested. Case 45-55-2, a PFSA-FEP blend, showed promise, having significantly lower $\mathrm{SO}_{2}$ transport $\left(1.99 \times 10^{-8} \mathrm{~cm}^{2}\right.$ $\left.\mathrm{s}^{-1}\right)$ than the baseline Nafion ${ }^{\circledR} 115\left(6.10 \times 10^{-8} \mathrm{~cm}^{2} \mathrm{~s}^{-1}\right)$ while having only a small decrease in performance $\left(228 \mathrm{~mA} \mathrm{~cm}^{-2}\right.$ vs. $\left.270 \mathrm{~mA} \mathrm{~cm}^{-2}\right)$. In general it was noted that most PFSA-type samples that had higher conductivities and electrolyzer performance also had higher $\mathrm{SO}_{2}$ transport, while most samples that had low $\mathrm{SO}_{2}$ transport also had low conductivity and exhibited poorer electrolyzer performance. 
Non PFSA-type membranes were also tested including SDAPP, S-PFCBs, and PBI. SDAPP membranes were originally developed as a low cost alternative to PFSA with improved thermal stability while maintaining good chemical stability, ionic conductivity, and barrier properties to small neutral molecules. Sulfonation of Diels-Alder polyphenylenes results in a membrane that has excellent proton conductivity $\left(0.0328 \mathrm{~S} \mathrm{~cm}^{-1}\right)$. SDAPP membranes employ the same proton conduction mechanism as PFSA, where sulfonic acid groups generate water channels inside the membrane which solvate and transport protons [7]. The SDAPP membrane performed well in the HyS electrolyzer $\left(286 \mathrm{~mA} \mathrm{~cm}{ }^{-2}\right)$, slightly higher than Nafion ${ }^{\circledR} 115\left(270 \mathrm{~mA} \mathrm{~cm}^{-2}\right)$, however the $\mathrm{SO}_{2}$ transport was similarly increased $(7.79 \mathrm{x}$ $10^{-8} \mathrm{~cm}^{2} \mathrm{~s}^{-1}$ vs. $6.10 \times 10^{-8} \mathrm{~cm}^{2} \mathrm{~s}^{-1}$ ). Thermal gravimetric analysis indicates SDAPP stability of up to $285{ }^{\circ} \mathrm{C}$ where $\mathrm{SO}_{3}$ cleavage initiates, while DSC indicates a $\mathrm{T}_{\mathrm{g}}$ well above the decomposition temperature [9]. Future testing will take advantage of this increased thermal stability which is expected to increase HyS electrolyzer performance by decreasing the kinetic overpotential.

Sulfonated perfluorocyclobutyl aromatic ether polymer (S-PFCBs) electrolytes were initially developed by Smith and co-workers at Clemson and Tetramer Technologies, LLC, for automotive PEM fuel cells $[13,14]$. Currently a variety of PFCB polymers and copolymers are under development, including BPVE and BPVE-6F, which are designed specifically for use in a HyS electrolyzer cell with the primary goal of suppressing $\mathrm{SO}_{2}$ transport. The BPVE membrane, $\mathrm{B}(2)$, and BPVE-6F membranes, B1F1(1), and B2F1(3), all displayed high $\mathrm{SO}_{2}$ flux $\left(21.2,16.2\right.$, and $17.6 \mathrm{~mol} \mathrm{SO}_{2} \mathrm{~s}^{-1} \mathrm{~cm}^{-2}$ respectively), however this is mostly a function of their relative thickness, all of which are less than $25 \mu \mathrm{m}$ (1 mil). The $\mathrm{SO}_{2}$ transport, which takes the membrane thickness into account, was found to be significantly lower than the baseline material $\left(6.10 \times 10^{-8} \mathrm{~cm}^{2} \mathrm{~s}^{-1}\right)$ in all 3 membranes $(\mathrm{B}(2)=3.50, \mathrm{~B} 1 \mathrm{~F} 1(1)=2.37$, and $\left.\mathrm{B} 2 \mathrm{~F} 1(3)=3.07 \times 10^{-8} \mathrm{~cm}^{2} \mathrm{~s}^{-1}\right)$ while displaying increased electrolyzer performance (320, 337, and $335 \mathrm{~mA} \mathrm{~cm}^{-2}$ respectively). A comparison to a PFSA membrane of similar thickness like Nafion ${ }^{\circledR} 211$, however, may be more appropriate. All three BPVE membranes now show reduced $\mathrm{SO}_{2}$ flux despite being thinner still, and lower $\mathrm{SO}_{2}$ transport, while their conductivity and electrolyzer performance are somewhat lower than the excellent performance from Nafion ${ }^{\circledR} 211\left(393 \mathrm{~mA} \mathrm{~cm}^{-2}\right)$. BPVE-6F (1:1) showed the best combination 
of $\mathrm{SO}_{2}$ transport, conductivity, and performance and will undergo further testing and development.

The PBI family of membranes were originally developed for Phosphoric Acid (PA) fuel cells and are known for their ability to operate at elevated temperatures and without humidification $[15,16]$. Unlike sulfonated membranes (PFSA, SDAPP, BPVE), that employ sulfonic acid groups to transport hydrated protons, PBI membranes employ a hopping mechanism in which immobilized anions, such as PA, can solvate protons whereby providing a path for rapid proton exchange. As a result, protons are conducted without the need of water channels. This can greatly reduce the transport of small neutral molecules, which is reflected in both the measured $\mathrm{SO}_{2}$ flux $\left(2.14 \times 10^{-9}\right.$ mol $\left.\mathrm{SO}_{2} \mathrm{~s}^{-1} \mathrm{~cm}^{-2}\right)$ and $\mathrm{SO}_{2}$ transport $\left(1.99 \times 10^{-8} \mathrm{~cm}^{2} \mathrm{~s}^{-1}\right)$, both of which are significantly lower than the baseline membrane. Amazingly, the HyS electrolyzer performance was also increased relative to the baseline (344 $\mathrm{mA} \mathrm{cm}^{-2}$ vs. $270 \mathrm{~mA} \mathrm{~cm}^{-2}$ ) indicating an effective proton exchange mechanism despite the decreased $\mathrm{SO}_{2}$ transport. This combination of significantly improved performance and reduction of $\mathrm{SO}_{2}$ transport make the $\mathrm{PBI}$ family of membranes a promising alternative demanding further study.

\subsection{ELECTROCATALYST STABILITY}

Consecutive CVs were performed to study the stability of the catalyst and the different electrochemical reactions occurring at the surface of the electrode in the absence of $\mathrm{SO}_{2}$. During the CVs, the current was monitored as a function of a set potential which is varied at a constant rate. Figure 7 shows the typical consecutive $\mathrm{CVs}$ for $\mathrm{Ru} / \mathrm{C}$ measured at room temperature in $30 \mathrm{wt} \% \mathrm{H}_{2} \mathrm{SO}_{4}$ in the absence of $\mathrm{SO}_{2}$. Two peaks are readily observed, corresponding to the oxidation-reduction of metal and desorption-adsorption of hydrogen on the catalyst surface. The high potential peak shows the monolayer oxide formation-reduction of the catalyst layer in $30 \mathrm{wt} \% \mathrm{H}_{2} \mathrm{SO}_{4}$ is observed. The low potential peak in the potential 
region between 0.24 and $0.1 \mathrm{~V}$ vs. SHE corresponds to the hydrogen adsorption-desorption on the catalyst surface.

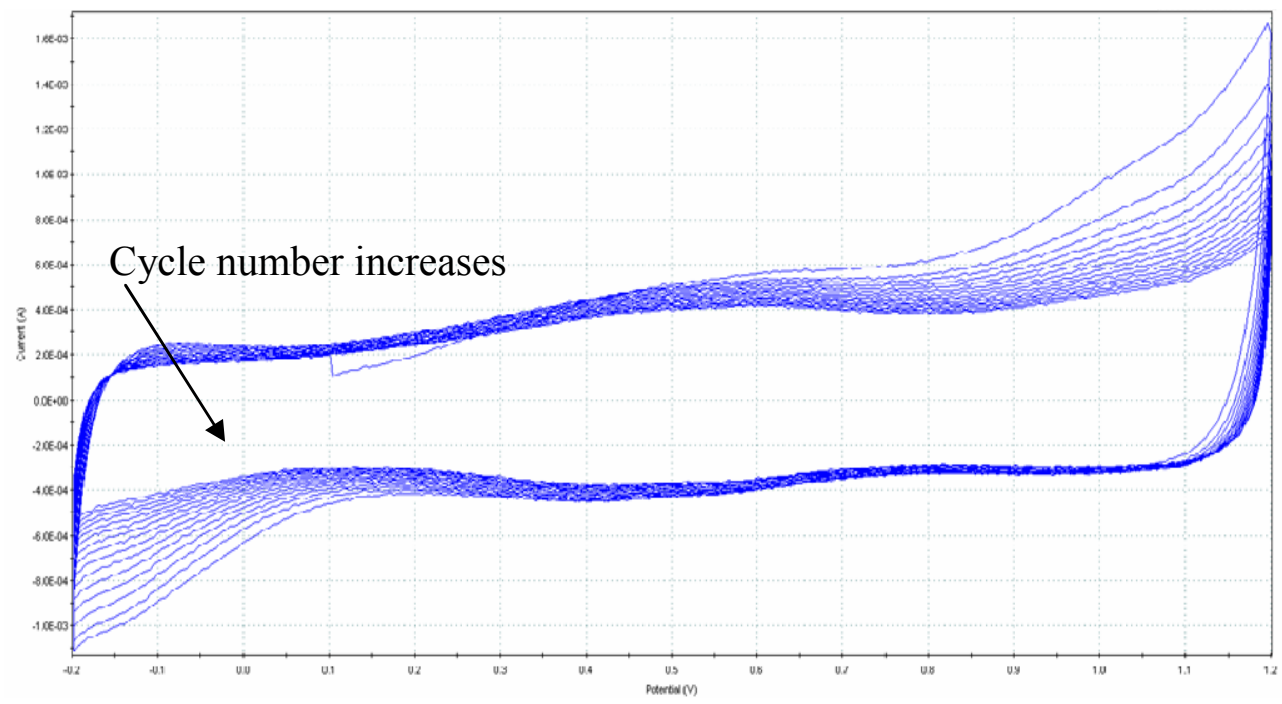

Figure 7. Typical cyclic voltammograms after consecutive cycling for $\mathrm{Ru} / \mathrm{C}$ in $30 \mathrm{wt} \%$ $\mathrm{H}_{2} \mathrm{SO}_{4}$ purged with $\mathrm{N}_{2}$ at room temperature.

In general, the area under the hydrogen adsorption-desorption peak gives an idea of the electrochemically active surface area available for reaction. The difference in the hydrogen desorption peak height after consecutive cycling can be observed in Figure 7. In the case of the $\mathrm{Pt} / \mathrm{C}$ and the $\mathrm{PtM} / \mathrm{C}(\mathrm{M}=\mathrm{Co}, \mathrm{Cr}, \mathrm{Fe})$ catalyst, the peak tends to increases until it stabilizes, see Figure 8a. The initial increase could correspond to a combination of wetting by the electrolyte of the catalyst surface and activation of the catalyst surface. In the case of $\mathrm{PtM} / \mathrm{C}(\mathrm{M}=\mathrm{Ru}, \mathrm{Ir})$ and $\mathrm{Ru} / \mathrm{C}$ the surface area progressively decreases with each cycle, see Figure $8 b$. 
A reduction in the peak area will indicate a reduction of active sites due to agglomeration of metal particles on the support, dissolution of metal in the electrolyte, or deactivation of active sites due to a poisoning agent.
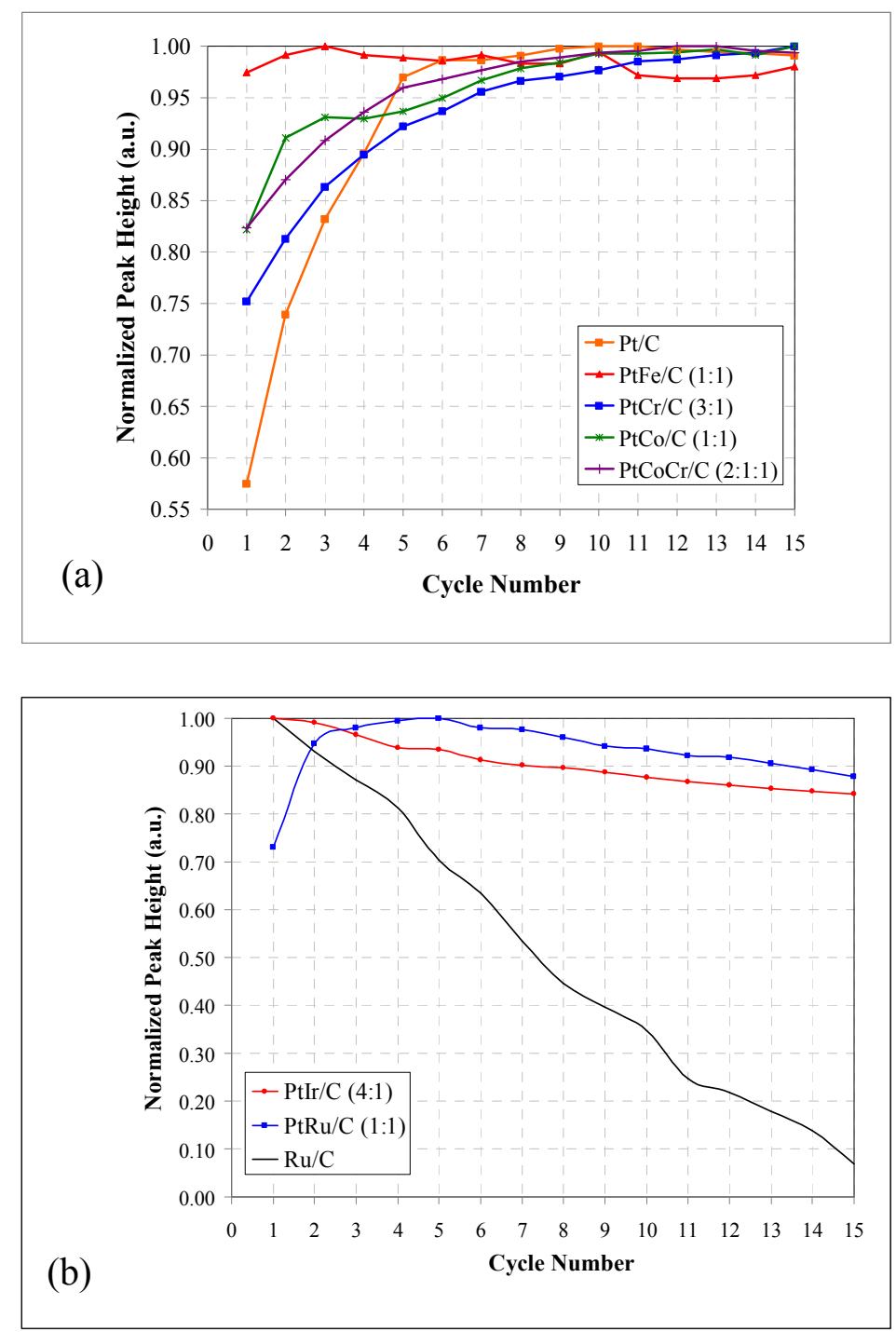

Figure 8. Normalized hydrogen desorption peak height after consecutive cycling for (a) $\mathrm{Pt} / \mathrm{C}$ and $\mathrm{PtM} / \mathrm{C}(\mathrm{M}=\mathrm{Co}, \mathrm{Cr}, \mathrm{Fe})$ and (b) $\mathrm{Ru} / \mathrm{C}$ and $\mathrm{PtM} / \mathrm{C}\left(\mathrm{M}=\mathrm{Ru}\right.$, Ir) in $30 \mathrm{wt} \% \mathrm{H}_{2} \mathrm{SO}_{4}$ purged with $\mathrm{N}_{2}$ at room temperature.

\subsection{ELECTROCATALYST ACTIVITY}


Selecting the right catalyst will have an impact on the electrical efficiency by allowing the SDE to operate at conditions closer to the reversible potential. The electrocatalytic activity of the Pt base catalysts was investigated for the oxidation of $\mathrm{SO}_{2}$ in $30 \mathrm{wt} \%$ sulfuric acid solutions at room temperature. The typical LSV is shown in Figure 9 in the form of Tafel plot as the catalyst is cycled. LSVs measuring $\mathrm{SO}_{2}$ oxidation for platinum and all platinum alloys revealed this interesting trend. Subsequent LSVs showed a rapid decrease in equilibrium potential measurements on a per cycle basis. Initially the decrease in potential was pronounced. After multiple cycles, the drop in potential decreases until finally after 15 or more cycles the equilibrium potential stabilizes. The behavior indicates the possible activation of the catalyst surface, such as the formation of a layer of adsorbed sulfur species on the catalyst surface [17]. Figure 10 shows a summary of the initial open circuit potential (OCP) when the electrode is inserted in the fresh solution and after the electrode is cycled and an steady OCP is obtained. It is interesting to note that the best end OCP is observed when $\mathrm{Pt}$ is alloyed with non-noble metals such as cobalt, chromium or iron and the abundance of non-noble metal atoms is higher than Pt. However, when Pt is alloyed with noble metals such as iridium or ruthenium the OCP is similar to Pt or higher.

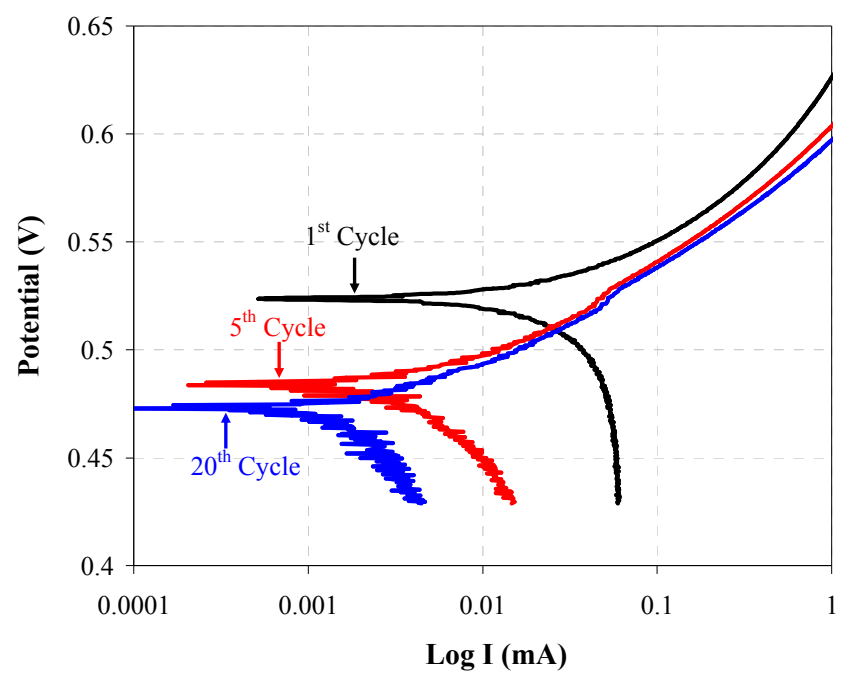

Figure 9. Typical Tafel plot for $\mathrm{PtCr} / \mathrm{C}$ in $30 \mathrm{wt} \%$ sulfuric acid, saturated with $\mathrm{SO}_{2}$ at room temperature. Three different potential cycles are shown. 


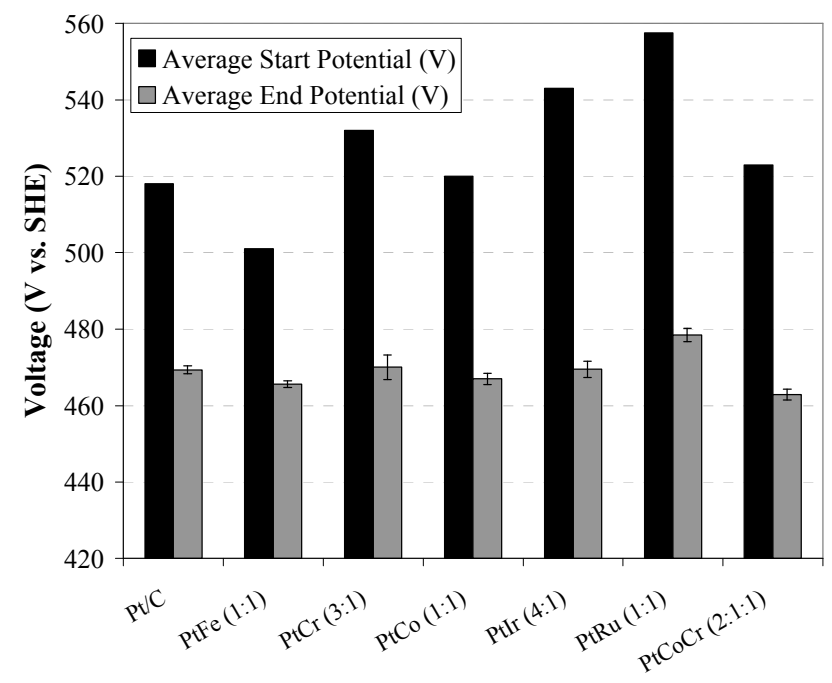

Figure 10. Open circuit potential for the different catalysts at the beginning of the test and after reaching near steady state conditions. Tested in $30 \mathrm{wt} \%$ sulfuric acid, saturated with $\mathrm{SO}_{2}$ at room temperature. 


\subsection{CONCLUSIONS}

Progress has been made in identifying PEMs that exhibit reduced transport of $\mathrm{SO}_{2}$. Of the PFSA-type membranes, the Dupont bilayer, the 1500EW membrane, the two treated PFSA membranes from Dupont, and the PFSA-FEP blends from Case Western Reserve University all showed reduced $\mathrm{SO}_{2}$ transport relative to the baseline membrane Nafion ${ }^{\circledR} 115$. Of the non-PFSA membranes, BPVE and BPVE-6F from Clemson University, and the Celtec-V PBI membrane from BASF also showed reduced $\mathrm{SO}_{2}$ transport. Only the BPVE, BPVE-6F, and PBI membranes exhibited increased electrolyzer performance coupled with lower $\mathrm{SO}_{2}$ transport. The PBI membrane, Celtec- $\mathrm{V}$, exhibited the best combination of performance and $\mathrm{SO}_{2}$ transport, with a $27 \%$ increase in current density and a $67 \%$ decrease in $\mathrm{SO}_{2}$ transport, compared to the baseline membrane Nafion ${ }^{\circledR} 115$.

It should be noted that all of the non-PFSA type membranes tested were either designed for or should be capable of operating at higher temperatures (PBI $<200{ }^{\circ} \mathrm{C}$, SDAPP $<285{ }^{\circ} \mathrm{C}$, BPVE- $\left.6 \mathrm{~F}>100^{\circ} \mathrm{C}\right)$ than that allowed in the current testing system $\left(80^{\circ} \mathrm{C}\right)$ all. Future work will involve testing at elevated temperatures $\left(120{ }^{\circ} \mathrm{C}\right)$ and pressures. The increase in operating temperature is expected to decrease the kinetic overpotential loss thereby increasing the electrolyzer performance, for the high temperature membranes, SDAPP, BPVE-6F, and PBI.

The stability and activity of anode and cathode catalysts at $30 \mathrm{wt} \%$ acid concentration was studied on commercially available catalysts. It is desired for the SDE to have catalysts with high chemical and electrochemical stability. Among the catalysts tested $\mathrm{Pt} / \mathrm{C}$ and $\mathrm{PtM} / \mathrm{C}$ $(\mathrm{M}=\mathrm{Co}, \mathrm{Cr}, \mathrm{Fe})$ showed good stability, while catalysts containing Ir or $\mathrm{Ru}$ showed degradation as a function of cycling. The $\mathrm{SO} 2$ oxidation activity of the different catalysts was improved for catalysts with higher atomic concentration of non-noble metals such as cobalt, chromium or iron than Pt. However, when Pt is alloyed with noble metals such as iridium or ruthenium the OCP is similar to Pt or higher. 


\subsection{REFERENCES}

1. J. Udagawa, P. Aguiar, N. P. Brandon. Journal of Power Sources. 166 (2007) 127.

2. J. E. Funk. International Journal of Hydrogen Energy. 26 (2001) 185.

3. M. B. Gorensek, J. A. Staser, T. G. Stanford, J. W. Weidner. International Journal of Hydrogen Energy, 34 (2009) 6089-6095.

4. Westinghouse Electric Corporation, A Study on the Electrolysis of Sulfur Dioxide and Water for the Sulfur Cycle Hydrogen Production Process, AESD-TME-3043, July 1980.

5. J. L. Steimke, T. J. Steeper, Characterization Testing of $\mathrm{H}_{2} \mathrm{O}-\mathrm{SO}_{2}$ Electrolyzer at Ambient Pressure, Westinghouse Savannah River Company, Technical Report WSRCTR-2005-00310, August 1, 2005.

6. J. L. Steimke, T. J. Steeper, Characterization Testing and Analysis of Single Cell SO2 Depolarized Electrolyzer, Washington Savannah River Company, Technical Report WSRC-STI-2006-00120, September 15, 2006.

7. K. A. Mauritz, R. B. Moore. Chem. Rev. 104 (2004) 4535-4585.

8. L. Xiao, H. Zhang, E. Scanlon, L. S. Ramanathan, E. Choe, D. Rogers, T. Apple, B. C. Benicewicz. Chem. Mater. 17 (2005) 5328-5333.

9. C. H. Fujimoto, M. A. Hickner, C. J. Cornelius, D. A. Loy. Macromolecules. 38 (2005) 5010-5016.

10. J. Jin, J. Stanbro, D. Van Derveer, D. W. Smith. PMSE Preprints. 91 (2004) 504-505.

11. R. Bouchet, E. Siebert. Solid State Ionics 118 (1999) 287-299.

12. X. Glipa, B. Bonnet, B. Mula, D. J. Jones, J. RozieÁre, J. Mater. Chem. 9 (1999) 30453049.

13. K. A. Perry, G. A. Eisman, B. C. Benicewicz. Journal of Power Sources. 177 (2008) 478-484.

14. C. B. Shogbon, J. Brousseau, H. Zhang, B. C. Benicewicz, Y. A. Akpalu. Macromolecules. 39 (2006) 9409-9418.

15. J. L. Steimke, T. J. Steeper, D. T. Herman, H. R. Colon-Mercado, M. C. Elvington. Savannah River Nuclear Solutions, Technical Report SRNS-STI-2009-00134, September 15, 2006.

16. A. Shaver, H. Boily, A. Lebuis. Inorganic Chemistry. 35 (1996) 6356-6357. 
17. C. Quijada, J. L. Vazques, A. Aldaz. Journal of Electroanalytical Chemistry. 414 (1996) 229-233. 